\title{
Passing-On Defense and Indirect Purchaser Standing in Actions for Damages against the Violations of Competition Law: what can the EC learn from the US?
}

by

\author{
Firat Cengiz \\ ESRC Centre for Competition Policy and School of Law, University \\ of East Anglia
}

\section{CCP Working Paper 07-21}

\begin{abstract}
This paper analyses the raison d'être of the current initiative for the federal policy change in the US regarding the issues of passing-on defense and indirect purchaser standing in order to draw policy lessons for the EC in the light of the Commission's Green Paper on private enforcement of Community competition law. The paper finds that transatlantic policy learning in the substantive sense does not seem plausible due to the dramatic difference between the American rationale regarding the goals of private enforcement and the European doctrine of direct effect. Nevertheless, the paper argues that the US experience contains important policy lessons regarding the risks brought forward by private enforcement under diverse standards in the lack of effective judicial cooperation mechanisms in a multilevel polity. After analysing the current positions of the Community and national laws from this perspective, the paper finds that there is substantial room for diversity amongst the national standards. In addition, although existing Community measures provide solid ground for judicial cooperation, those measures should be strengthened in order to avert the litigation chaos which forced a policy change in the US. Consequently, the paper suggests that the Commission gives substantial weight to the procedural aspects of private enforcement in its forthcoming White Paper which the Green Paper largely overlooked.
\end{abstract}

November 2007 
JEL Classification Codes: K21, K41

Keywords: Private enforcement, indirect purchasers, Passing-on defense, Illinois Brick, Hanover Shoe, Antitrust Modernization Commission, European Commission Green Paper on actions for breach of the EC Antitrust Rules, Brussels I Regulation, Rome II Regulation

\section{Acknowledgements:}

The author is indebted to Mr. Ersin Ozkan for his kind support. She has also benefited very much from discussions she had with Miss Kathryn Wright. The usual disclaimer applies. Financial contributions of the British Government, Economic and Social Research Council, Centre for Competition Policy and the Faculty of Social Sciences of the UEA are greatly acknowledged. The support of the Economic and Social Research Council is also gratefully acknowledged.

\section{Contact details:}

Firat Cengiz, Centre for Competition Policy, University of East Anglia, Norwich, NR4 7TJ, UK.

f.cengiz@uea.ac.uk 


\section{Introduction}

Actions for damages brought by the injured parties against the individuals and/or undertakings involved in violations of competition law correct the harmful effects of such activities to a certain extent, deter anticompetitive activities and thereby complement the enforcement efforts of competition authorities. ${ }^{1}$ Therefore, it is widely accepted that an effective private enforcement regime constitutes a vital element of a modern antitrust system. ${ }^{2}$ Realising the potential benefits of private enforcement, the European Commission has been actively seeking ways of establishing a Communitywide private enforcement regime by invigorating actions for damages before the national courts against the violations of Community competition law.

In 2004 the Modernisation movement transformed Article 81(3) EC into a legal exception rule and thereby abolished the individual exemption regime which granted the Commission enforcement monopoly. The Modernisation Regulation explicitly certified that, from then on, the national courts would have the authority to enforce Articles 81 and 82 EC in their entirety. ${ }^{3}$ Nevertheless, this new authority did not engender the expected enthusiasm nor any activism in private enforcement. For instance, a study by the Commission revealed that the current picture regarding the private actions before the national courts is one of "astonishing diversity and total underdevelopment". 4 In order to attract the attention of the antitrust community to the problem and initiate a discussion on the various policy options regarding particulars of private enforcement, the Commission published a Green Paper in $2005 .{ }^{5}$ One of the issues specifically raised by the Commission's Green Paper was whether or not the indirect purchasers, including final consumers, as well as direct purchasers should be entitled to

\footnotetext{
${ }^{1}$ Andrew I. Gavil, Federal Judicial Power and the Challenges of Multijurisdictional Direct and Indirect Purchaser Antitrust Litigation, 69 George Washington Law Review 860 2000, at 860.

${ }^{2}$ See e.g. Clifford A. Jones, "Private Antitrust Enforcement in Europe: A Policy Analysis and Reality Check", World Competition, 2004, 27(1):13-24 in contrast to Wouter P.J. Wils, "Should Private Enforcement be Encouraged in Europe?", World Competition, 2004, 27(1):13-24.

${ }^{3}$ Council Regulation (EC) No 1/2003 of 16 December 2002 on the application of Articles 81 and 82 of the Treaty, 4.1.2003 OJ L 1/1, Arts. 1 and 6.

${ }^{4}$ Ashurst, Study on the Conditions of Claims for Damages of Infringement of EC Competition Rules, Comparative Report (hereinafter "Comparative Report"), 31 August 2004, at 1, available at

http://ec.europa.eu/comm/competition/antitrust/others/actions for damages/comparative report clean en.pdf

${ }^{5}$ Commission of the European Communities, Green paper, damages actions for breach of the EC Antitrust Rules (hereinafter the "Green Paper"), Brussels, 19.12.2005, COM(2005) 672 final, available at http://eurlex.europa.eu/LexUriServ/site/en/com/2005/com2005 0672en01.pdf.
} 
claim damages against violations of Articles 81 and 82 EC. Inextricably linked to the question of indirect purchaser standing, the Green Paper also asked whether or not the passing-on defense should be recognised in Europe. ${ }^{6}$

Without any doubt, with a more than a century old private enforcement regime, the US constitutes a valuable source of several potentially useful positive as well as negative policy lessons for the EC with respect to the design of individual elements of private enforcement. Particularly, recent initiatives for changing the federal policy regarding passing-on defense and indirect purchaser standing imply that analysis of the US experience regarding these issues might provide important policy lessons for the EC. As is widely known, the Supreme Court had denied both the passing on defense and the indirect purchaser standing in damage actions against the violations of federal antitrust laws with its twin judgements of Hanover Shoe ${ }^{7}$ and Illinois Brick ${ }^{8}$. The Antitrust Modernization Commission, which was founded in 2002 to study the procedural and the substantive aspects of the federal antitrust policy, recently recommended in its final report that both doctrines be overruled through legislative amendment. ${ }^{9}$ This Paper aims to analyse the US experience of the passing-on defense and the standing of indirect purchasers together with the motivations behind the recent initiative of policy change in order to draw policy lessons for the EC regarding these matters. With the Commission's White Paper on private enforcement yet to come, such analysis has the potential to offer important lessons for the future direction of EC competition policy.

The Paper starts with a brief explanation of the problems of passing-on defense and indirect purchaser standing. It argues that, like other aspects of private antitrust enforcement, matters of passing-on defense and indirect purchaser standing incorporate three main elements: fairness, effectiveness and efficiency.

\footnotetext{
${ }^{6}$ Id., Question G at p. 8.

7 Hanover Shoe v. United Shoe Machinery Corp. 392 U.S. 481 (1968) (hereinafter "Hanover Shoe").

${ }^{8}$ Illinois Brick Co. v. Illinois 431 US 720 (1977) (hereinafter "Illinois Brick").

${ }^{9}$ Antitrust Modernization Commission, Report and Recommendations (hereinafter "AMC Final Report"), April 2007, available at http://www.amc.gov/report recommendation/amc final report.pdf, at 267.
} 
The paper argues that there are essential trade-offs between these perspectives, and that ultimately the policy choice of any individual polity regarding the passing-on defense and the standing of indirect purchasers will depend on which of these three elements is valued the most.

The second part of the Paper analyses the history of US policy and the current initiative for the alteration of such policy. It finds that the conventional wisdom in the US predominantly values effectiveness over the other elements of private enforcement, and that due to the dramatic difference between American and European understandings of effectiveness, the possibility of policy learning from the US in the substantive sense appears rather limited. As it emerges from the rationales of the Supreme Court and the antitrust community, the American understanding of effectiveness mainly and strictly centres on the notion of deterrence, and consequently, policy design requires the granting of a monopoly of standing to the class of plaintiffs with the greatest incentives to sue and superior resources to invest in litigation. The European understanding, on the other hand, attaches substantial value to effective enforcement of the directly effective rights of individuals stemming from the Community law and therefore disapproves the imposition of limits on the classes of plaintiffs who are entitled to bring actions for damages against the violations of Community competition law.

In contrast to the limited possibility of policy learning in the substantive aspects of the matter, the Paper finds that the US experience provides potentially useful lessons for the EC in terms of the procedural issues. The initiative for policy change in the US was not provoked by a shift in legal and economic philosophy or a socio-economic transformation which rendered the current policy redundant. On the contrary, the conventional wisdom still considers the policy of eliminating both passing-on defense and indirect purchaser standing the best option particularly from an effectiveness standpoint. Rather, it was the existence of federal and various state laws embracing diverse approaches regarding the matter, and the lack of effective cooperation mechanisms amongst the judiciary which turned the US private enforcement regime into a chaotic one and required action for a policy change at the 
federal level. From this angle, the US experience clearly illustrates that under diverse substantive standards and in the lack of effective procedural coordination mechanisms, it is not realistic to expect the emergence of a coherent and effective private enforcement regime.

The last part of the paper explores the current position of Community law regarding passing-on defense and indirect purchaser standing and Community measures of judicial cooperation in cross-border litigation. It finds only inconclusive direction from the Community level and diverse approaches at the national level regarding the passing-on defense and indirect purchaser standing. In terms of procedural mechanisms of coordination, it argues that although certain progress has been made through Community initiatives of procedural harmonisation and inter-court coordination, substantial room for improvement still exists. It concludes that without either harmonised and uniform substantive standards across Europe or solid procedural mechanisms through which various national courts can adjudicate different claims regarding the same violation under a single substantive standard, a private enforcement regime will either never flourish in Europe or, as the US experience clearly illustrates, it will result with a chaotic litigation environment which is extremely costly for the parties to manage and impossible for the policy-makers to give direction to. In other words, although it is a politically sensitive matter, without a certain compromise on either national procedural autonomy or autonomy on the design of substantive standards regarding passing-on defense and indirect purchaser standing, it is unrealistic to expect the emergence of an effective private antitrust enforcement in Europe. In connection, the paper argues that the Commission might be making a strategic mistake by overlooking the procedural aspects of private enforcement in its Green Paper. Consequently, it calls the Commission to address these issues in its forthcoming White Paper.

\section{The problems of passing-on defense and indirect purchaser standing and the law and economics literature regarding these problems}

Generally all products pass through a production chain before they reach the final consumer. When market forces are superseded in any level of this chain 
through the formation of a cartel or an abuse of a dominant position, all purchasers below that level including final consumers may have to face higher prices, scarce output and a restricted choice between products and services. In a very simple example of a product chain which consists of a manufacturer, a retailer and a final consumer, when the manufacturer takes part in a pricefixing cartel and raises his prices, in the first instance the retailer bears the overcharge and then he faces a choice between different pricing options when selling the product to the final consumer. Depending on the economic circumstances and the market structure his main choices are absorbing all of the overcharge and not reflecting economic effects of the cartel on the prices he is charging to the final consumer; passing-on of all of the overcharge to the final consumer by raising his prices so as to include the whole of the overcharge; and finally, absorbing a part of the overcharge while passing-on the rest to the final consumer. In an ideal world, we would expect the legal system to provide mechanisms whereby both the retailer (the direct purchaser) and the final consumer (the indirect purchaser) can claim damages in the amount exactly equal to their individual economic losses - of course, had they faced any. But unfortunately, in the real world market structures are complex, economic decisions are hard to analyse ex post and judicial processes get easily overwhelmed and blocked by claims involving complex economic analyses. Therefore, when designing private antitrust enforcement regime, each jurisdiction faces a vital policy choice as to whether to allow the passing-on defense and the indirect purchaser standing or not. When the passing-on defense is allowed, the defendant facing a damage claim (in our example the manufacturer) is entitled to argue that the plaintiff (in our example the retailer) passed the overcharge on to the person below him in the production chain (in our example the final consumer) and upon proving such claim successfully, he escapes damage liability. Inextricably linked to this is the question whether the indirect purchasers (in our example the final consumer) as well as the direct ones (in our example the retailer) be given standing to claim damages they have incurred as a result of an anticompetitive activity. 
As it is mentioned in the introduction, like any other aspect of a private enforcement regime, questions of passing-on defense and indirect purchaser standing incorporate three main elements: ${ }^{10}$

(i) The fairness element which requires that every individual including final consumers should be entitled to claim damages in order to make good any injury they have incurred as a result of illegal behaviour,

(ii) The effectiveness element which perceives deterrence of anticompetitive activities as the ultimate goal of private enforcement and consequently requires granting of a standing monopoly to the most superior one amongst the classes of potential plaintiffs,

(iii) And finally, the efficiency element which places the issue of judicial economy and potential burdens imposed on judicial processes at the heart of the policy decision.

There are unavoidable connections and clashes between these elements. On the one hand, a private enforcement regime where all injured parties including the final consumers are entitled to compensation would deter anticompetitive behaviour - albeit imperfectly - and rational individuals are expected to utilise the private enforcement mechanisms so long as the benefits of doing so outweigh the costs, in other words, as long as such mechanisms prove efficient from their perspectives. But on the other hand, the fairness element unavoidably comes into conflict with the elements of effectiveness and efficiency. Fairness requires recognition of both indirect and direct purchaser standing and passing-on defense so that each cluster of plaintiffs would be able to receive compensation just in the amount of damages they have incurred. In that case no class of plaintiffs would receive any windfall benefits at the expense of others. But realisation of this ideal to the full extent raises serious impediments to deterrence and judicial economy, as it requires adjudication of complex and speculative economic issues. In order to calculate the exact amount of damages which each group of plaintiffs have

\footnotetext{
${ }^{10}$ See e.g. Valerie Sarris, "The Efficiency of Private Antitrust Enforcement: The Illinois Brick Decision", Garland Publishing, New York, London, 1984, at 117; Gavil, supra note 1, at 860; Barak D. Richman, Christopher R. Murray, "Rebuilding the Illinois brick: a Functionalist Approach to the Indirect Purchaser Rule", Duke Law School Legal Studies Research Paper Series, no. 155, May 2007, at 3.
} 
incurred, the judiciary will have to analyse complex market structures and pricing decisions ex post. Additionally, in the real world, production chains are much longer and more complicated than the example of the three-level production chain given above. For instance, in some cases one product becomes a component of another one at some level in the production chain rendering it extremely difficult for the judiciary even to determine who the direct and who the indirect purchaser is.

Due to this unavoidable clash between the elements of fairness, effectiveness and efficiency, polities generally design their policies depending on which one of these elements they value the most. Naturally, one turns to the legal and economic literature at this point in order to draw some policy lessons. Unfortunately, however, the economics of passing-on is not straightforward and the legal and economic literature regarding the effects of the indirect purchaser standing on the effectiveness and efficiency of the private enforcement regime is - at least to a certain extent - inconclusive and politically driven.

Academic discussions regarding passing-on defense and the indirect purchaser standing still centre around two papers published by American scholars immediately after the delivery of Hanover Shoe and Illinois Brick judgments. The first paper by Landes and Posner follows a Chicago School rationale and eagerly applauds the Supreme Court's policy choice. ${ }^{11}$ In that paper Landes and Posner argue that there is an essential conflict between the goals of fairness and deterrence, and antitrust policy should exclusively seek to accomplish the second one. ${ }^{12}$ The deterrence goal requires granting of a standing monopoly to the direct purchasers as they stand closer to the conspirators in the production chain, enjoy superiority in terms of access to information and evidence regarding the violation, and consequently, they enjoy a better prospect of bringing successful damage actions. ${ }^{13}$ Recognition of passing-on defense and indirect purchaser standing would inevitably

\footnotetext{
${ }^{11}$ William M. Landes, Richard A. Posner, "Should Indirect Purchasers have Standing to Sue under the Antitrust Laws? An Economic Analysis of the Rule of Illinois Brick", 46 University of Chicago Law Review 6021979.

${ }_{12}$ Id., at 604 .

${ }^{13}$ ld., at 609 .
} 
require calculation of the exact amount of damages which these different groups have incurred and apportionment of the damage fund between them. These activities would require analysis of complex economic facts by the judiciary and render antitrust cases even more cumbersome than they already are. ${ }^{14}$ And finally - and perhaps naively - Landes and Posner argue that indirect purchasers themselves will also benefit from the standing monopoly of the direct purchasers. According to their model, with the expectation of compensation, direct purchasers will continue to buy the price-fixed product in the same amount as they used to do before the formation of the cartel which would decrease the expected marginal cost of the direct purchasers and thereby benefit the indirect purchasers in the form of lower prices. ${ }^{15}$

In another seminal paper, Harris and Sullivan strongly disagree with these arguments. They contend that passing-on of the overcharge to indirect purchasers depends mainly on the structure of the market and the price elasticity of the demand and supply. ${ }^{16}$ The more elastic the supply function of the direct purchaser - in other words, the more he is able to reduce his output in response to the price increase caused by the anticompetitive activity in the short run - the more he will be able to pass the overcharge down the production chain. Likewise, the less elastic the demand function of indirect purchasers - in other words, the less substitute products there are which they can effectively switch to in response to the price increase, the more able direct purchasers will be to pass-on the overcharge to indirect purchasers. Although calculation of the supply and demand elasticities might appear difficult for the judiciary in practice, Harris and Sullivan argue that this actually is not the case as in concentrated markets where anticompetitive activities take place, the conditions for the passing-on of the overcharge to final consumers hold $a$ priori. $^{17}$ In concentrated markets, demand of the direct purchaser is not expected to be very elastic, as the existence of anticompetitive activity presupposes that there are no good substitutes to switch. As the direct purchaser derives his demand function from that of the indirect purchaser, the

\footnotetext{
${ }^{14}$ Id. at 615.

${ }^{15}$ Id., at 605 .

${ }^{16}$ Robert G. Harris, Lawrence A. Sullivan, "Passing on the Monopoly Overcharge: A Comprehensive Policy Analysis",

128 University of Pennsylvania Law review 269 1980, at 273.

${ }^{17}$ Id., at 276.
} 
demand function of the indirect purchaser is not expected to be very elastic either. 18 Under these circumstances, the overcharge imposed by anticompetitive activity will almost always be passed-on to the final consumers. In other words, Lawrence and Sullivan argue for a presumption in favour of the passing-on of the overcharges to final consumers.

More recent accounts attempted to enlighten different aspects of the law and economics of passing-on of the overcharge and indirect purchaser standing. For instance, Werden and Schwartz put forward an economic model where they analysed incentives of different groups of plaintiffs to invest in litigation for damages under different combinations of indirect and direct purchaser standing. ${ }^{19}$ Their model suggests that when indirect as well as direct purchasers are granted standing, both groups will have weaker incentives for claiming damages and investing in litigation, as in the end the pie of damage fund will be split between those two groups. ${ }^{20}$ Furthermore, a consolidated action involving direct as well as indirect purchaser groups is unlikely to contribute to the efficiency of litigation by creating synergies. First of all, these groups are very likely to choose to free-ride on one another's efforts to bring evidence and prove the violation instead of investing in litigation. ${ }^{21}$ In such a case, they will end up in a situation of 'prisoners' dilemma' and jeopardise effectiveness of the private enforcement regime. Secondly, indirect and direct purchaser groups will represent clashing interests in litigation. Whereas in order to receive monetary relief indirect purchasers would naturally argue that the overcharge was passed-on to them, direct purchasers would attempt to establish that they are the class who absorbed the overcharge. ${ }^{22}$ For all these reasons, standing should be granted to only one of these groups as a monopoly right. From the effectiveness perspective, it should be direct purchasers holding such a monopoly as they are more likely to have access to the resources necessary for the funding of complex litigation. ${ }^{23}$ In addition,

\footnotetext{
${ }^{18} / d$., at 289.

${ }^{19}$ Gregory Werden, Marius Schwartz, "Illinois Brick and the Deterrence of Antitrust Violations- An Economic Analysis", 35 Hastings Law Journal 629, 1984.

${ }_{20}$ Id. at 651 .

${ }^{21}$ Id., at 654 .

${ }^{22}$ Id. However the model falls short of explaining why this is an undesirable situation exactly. Such race between the different clusters of plaintiffs to prove their argument is likely to stimulate them bring forward detailed economic evidence and analyses and thereby ameliorate the judiciary's burden of deciding on complex economic facts.

${ }_{23}$ Id., at 652 .
} 
indirect purchasers most probably have only weak incentives to bring damage claims as they are a highly diffused and atomised group consisting of potential claimants who individually bear only a small portion of the damages (for instance in the case of price-fixing in the rubber market think about the number of multinational companies producing tyres and the damage they have incurred as opposed to those of individual car owners who are the final consumers). ${ }^{24}$

Although these arguments appear quite persuasive at the first glance, other economic models fundamentally question their validity. First of all, as it is widely claimed, direct purchasers, in other words middlemen or resellers, generally share quite a close bond with their suppliers, particularly in the concentrated markets where anticompetitive activities take place. They have much more to lose from disturbing their relationship with their suppliers by bringing a damage claim, and therefore it is questionable whether they really have greater incentives to sue than the indirect purchasers. Secondly, antitrust policy should take the intelligence of the conspirators and their abilities to develop novel techniques to sustain collusion seriously. Undertakings would probably be aware that when they start a cartel or abuse their dominant positions, their customers would realise what is going on in the upstream market and consequently they might bring actions for damages. In order to avoid such actions the cartel members or the monopolists need to share a part of the overcharge with their purchasers. For instance, the "Illinois Wall" model asserts that it would be possible for the conspirators to share the profits of the anticompetitive activity with the undertakings in the downstream market through a simple, sustainable and tacit agreement. ${ }^{25}$ One possible tactic for the upstream firms is to systematically sell to each of the downstream firms only a limited amount of the input at a lower price, and thereby to create an artificial scarcity in the market for the final consumer

\footnotetext{
${ }^{24}$ Id.

${ }^{25}$ Maarten Pieter Schinkel, Jan Tuinstra, Jacob Ruggeberg, "Illinois Walls: How Barring Indirect Purchaser Suits Facilitates Collusion" (hereinafter 'Schinkel et al. "Illinois Walls"), Amsterdam Center for Law\& Economics Working Paper No. 2005-02, available at http://papers.ssrn.com/sol3/papers.cfm?abstract id=730384, see also Maarten Pieter Schinkel and Jan Tuinstra, "Illinois Walls in Alternative Market Structures", Amsterdam Center for Law\& Economics Working Paper Series, May 2005, available at

http://papers.ssrn.com/sol3/papers.cfm?abstract id=729843.
} 
products. ${ }^{26}$ Although there is no definite empirical data as to whether such an arrangement is enforceable in the real world, it is possible to encounter examples of cases where the conspirators incorporated their customers into the anticompetitive arrangement through various techniques in order to avoid a possible damage action or a complaint to the competition authorities. ${ }^{27}$

As it emerges from this brief summary of different models, legal and economic analyses of the passing-on of the overcharge through the production chain and the effects of passing-on defense and indirect purchaser standing on the effectiveness of the private enforcement regime is inconclusive. The literature approaches the matter mainly from the perspective of effectiveness and attempts to establish whether direct or indirect purchasers prove more efficient plaintiffs. The results however are not determinative as both indirect and direct purchasers suffer from substantial weaknesses under different circumstances. On the other hand, empirical studies comparing records of successful federal private actions pre- and post-Illinois Brick have been conducted specifically to reveal the effect of this judgment on the effectiveness of US federal antitrust policy. Those studies concluded that such effect was neutral at best. ${ }^{28}$

In summary, issues of indirect purchaser standing and passing on defense raise certain tensions between the elements of fairness, effectiveness and efficiency. The legal and economic literature falls short of proposing a logical solution to this dilemma. Under these circumstances, polities face a choice between different policy combinations which all appear imperfect as they disturb at least one of the three main elements of private enforcement. As stated in the Commission's Green Paper those options mainly are:

\footnotetext{
${ }^{26}$ Schinkel et. al., "Illinois Walls", id., at 6.

${ }^{27}$ See the examples of the lysine cartel where none of the direct purchasers such as Coca Cola or Procter \& Gamble did not bring a single action of damages (United States v. Ajinomoto Co., Inc. et al., no. 96-CR 520-1996), Microsoft where none among over the hundred of actions for damages were brought by direct purchasers, the case of Holiday Wholesale Grocery Co. et al. v. Philip Morris Incorporated, et al., No. 1:00-CV-0447-JOF where it is established that the upstream conspirator and the purchaser shared the cartel profit. All cited in Schinkel et al., id., at 30.

${ }^{28}$ See e.g. Edward S. Snyder, "Efficient Assignment of Rights to Sue for Antitrust Damages", Journal of Law and Economics, vol. 28 may 1985; Jon M. Joyce, Robert H. McGuckin, "Assignment of Right to Sue under Illinois Brick: An Empirical Assessment", Antitrust Bulletin Spring 1986, 31(1), 235-259 which analyse the empirical data regarding the damage actions brought before and after the Illinois Brick judgment but do not reach to any conclusive answer as to the effect of that doctrine on the effectiveness of antitrust enforcement.
} 
1) Recognition of both indirect and direct purchaser standing and passingon defense which, although is the ideal from the fairness perspective, may disturb effectiveness, ${ }^{29}$

2) Rejection of both indirect purchaser standing and passing-on defense which, although is the most compatible option with the efficiency perspective, seriously disturbs fairness, ${ }^{30}$

3) Rejection of passing-on defense and recognition of indirect as well as direct purchaser standing which would probably result with multiple recoveries and therefore comes into conflict with fairness, ${ }^{31}$

4) A two-step procedure where both indirect and direct purchasers can sue and damages are apportioned between the two classes in the second phase of the litigation. ${ }^{32}$ This option combines the three elements most optimally, but unfortunately it is likely to bring with technical complications. Management of such a process would require utilisation of strong judicial cooperation mechanisms particularly when the violation in question involves multiple national markets and therefore engenders proceedings before multiple national courts.

This Paper will eventually come back to the plausibility of these options in the context of the European private enforcement regime. But now it turns to the US experience regarding passing-on defense and indirect purchaser standing in order to draw some policy lessons for the EC.

\section{American Federal Policy regarding Passing-on Defense and Indirect Purchaser Standing: Hanover Shoe and Illinois Brick}

Section 4 of the Clayton Act states that "any person who shall be injured in his business or property by reason of anything forbidden in the antitrust laws may sue" to obtain treble damages (emphasis added). ${ }^{33}$ In other words, the Clayton Act does not restrict standing to any group of plaintiffs. However, the Supreme Court has restricted the classes of plaintiffs who enjoy standing in antitrust damage actions since the foundational period of the US private

\footnotetext{
${ }^{29}$ Green paper, supra note 5, Option 21.

${ }^{30}$ Id., Option 22.

${ }^{31}$ Id., Option 23.

${ }^{32}$ Id., Option 24.

${ }^{33}$ U.S.C. 15 § 5(a).
} 
enforcement regime for various policy reasons. In its earlier jurisprudence, the Court attempted to address the issues of passing-on defense and indirect purchaser standing from the perspective of "remoteness" of the injury from the violation. This early approach produced inconsistent judgments most of the time. ${ }^{34}$ The Court specifically faced the issue of passing-on for the first time in Hanover Shoe. That case involved a damage claim brought by a shoe manufacturer against the supplier of machines which were used in shoe production. The plaintiff alleged that by means of the supply scheme where he refused to sell machines in favour of leasing them exclusively, the machine supplier violated Sherman Act Section II and caused injury to the plaintiff. The defendant responded to this argument by asserting that the plaintiff should not be entitled to claim damages, because he had passed on the overcharge to his customers and hence, he had not incurred any damages. The court approached the matter exclusively from the perspective of efficiency and effectiveness and as a result, refused the passing-on defense.

First of all, the court observed that pricing decisions of an undertaking were highly individualised and influenced by a wide range of factors. ${ }^{35}$ These factors were particularly complex to analyse ex post. ${ }^{36}$ Additionally, even if it were easy to establish that the overcharge was passed on to the consumers, that would not necessarily mean that the plaintiff did not incur any injury as he may very well have faced a reduction in the number of units he sells due to the price increase. ${ }^{37}$ And, "in the real economic world rather than an economist's hypothetical model" it would be very difficult to determine what real effect the price increase had on the total sales of the defendant. ${ }^{38}$ As a result, since the analysis of passing-on defense would require convincing proof of "virtually unascertainable figures", the task would prove "insurmountable", and render the already complex antitrust damage actions totally unmanageable. ${ }^{39}$

\footnotetext{
${ }^{34}$ See Earl E. Pollock, "Standing to Sue, Remoteness of Injury, and the Passing-on Doctrine", 32 Antitrust Law Journal 5 1966; compare to Keogh v. Chicago \& N.W. Ry., 245 U.S. 531 (1918); Ohio Valley Electric Corp. v. General Electric Co., 244 F.Supp. 914 (S.D.N.Y. 1965); Commonwealth Edison v. Allis-Chalmers Mfg. Co., 315 F.2d 564 (7th Cir. 1963).

${ }^{35}$ Hanover Shoe, supra note 7 , at $492-93$.

${ }^{36} \mathrm{ld}$.

${ }^{37}$ ld.

${ }_{39}^{38} \mathrm{ld}$, at 493.
} 
Second, recognition of passing-on defense would automatically leave final consumers as the only group entitled to damages. In such a case damage actions "would be substantially reduced in effectiveness" as final consumers generally "have only a tiny stake in a lawsuit and little interest in attempting a class action". ${ }^{40}$ On all of these grounds, the Court rejected the defendant's argument and thereby established the federal policy of denying passing-on defense.

Nine years later, in Illinois Brick, the Court faced the question of indirect purchaser standing which constitutes the other side of the coin. In this case, the State of Illinois, who bought bricks as an indirect purchaser through the masonry contractors, sued the brick producers for damages caused by a price-fixing conspiracy. The Court denied standing to the State of Illinois mainly on three grounds: symmetry with Hanover Shoe, and the considerations of effectiveness and efficiency.

First of all, the Court observed that "whatever rule is to be adopted regarding pass-on in antitrust actions, it must apply equally to plaintiffs and defendants". ${ }^{41}$ Therefore, the Court was "faced with the choice of overruling (or narrowly limiting) Hanover Shoe or of applying it to bar respondents' attempts to use pass-on theory offensively". ${ }^{42}$ Otherwise, indirect as well as direct purchaser standing in the lack of passing-on defense would most probably result in multiple recoveries. ${ }^{43}$ Later on, this approach of the Court was criticised for being too formalistic and at odds with the substantive dynamics of antitrust policy. ${ }^{44}$ Some authors argued that perhaps allowing the possibility of multiple liability would be a better policy choice given that deterrence and not fairness appears to be the dominant consideration in the Court's jurisprudence starting with Hanover Shoe. ${ }^{45}$ In any case, the

\footnotetext{
${ }^{40}$ ld., at 494.

41 Illinois Brick, supra note 8, at 728.

${ }^{42} \mathrm{ld}$.

${ }^{43} / d$. , at 730

${ }^{44}$ Richman, Murray, supra note 10.

${ }^{45}$ See Prepared Statement of Professor Andrew I. Gavil Before the Antitrust Modernization Commission, June 27 2005 , available at

http://www.amc.gov/commission hearings/pdf/Gavil Statement corrected 6.27.05 version with app.pdf, at 14 .
} 
sequence of cases played a dramatic role in the development of American policy regarding passing-on defense and indirect purchaser standing. ${ }^{46}$ As Justice Blackmun observed in his dissent, "the plaintiffs-respondents in this case...[were] the victims of an unhappy chronology". 47

Additionally, Illinois Brick and Hanover Shoe constituted parts of the series of cases, such as Sylvania ${ }^{48}$ and Brunswick ${ }^{49}$, where the Court firmly incorporated Chicago School rationales which embrace economic efficiency

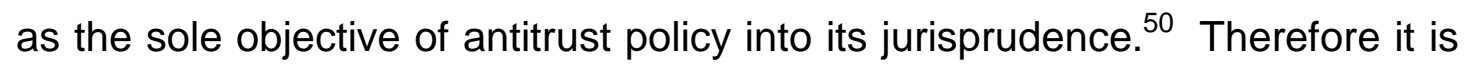
not surprising that the Court devoted significant attention to the notion of effectiveness in Illinois Brick and ignored the objective of compensating consumers. According to the Court, "the antitrust laws [would] be more effectively enforced by concentrating the full recovery for the overcharge in the direct purchasers rather than by allowing every plaintiff potentially affected by the overcharge ${ }^{\prime 51}$ to sue only for the amount it could show was absorbed by it. And lastly, taking the efficiency perspective, the Court referred to Hanover Shoe and mentioned once again the complex economic analyses which would be brought into the already complicated and costly antitrust damage litigation by indirect purchaser damage actions. ${ }^{52}$ Consequently, the Court established that the indirect purchasers were not entitled to bring actions for damages against the violations of federal antitrust law.

In Hanover Shoe and Illinois Brick, the Court had referred to some situations where the market forces are superseded and therefore complex economic analyses prove unnecessary for the calculation of damages. ${ }^{53}$ In its later judgments, the Court exempted such situations from the federal policy of denying indirect purchaser standing. For instance in cases where the middleman is owned or controlled by either the upstream producer or the

\footnotetext{
${ }^{46}$ Andrew I. Gavil, "Antitrust Remedy Wars Episode I: Illinois Brick from Inside the Supreme Court”, 79 St. John's L. Rev. 5532005.

47 Illinois Brick, supra note 8, (Blackmun, J. dissenting), at 765

${ }^{48}$ Continental TV, Inc. v. GTE Sylvania Inc., 433 U.S. 36 (1977) holding that the vertical territorial restrictions are not illegal per se.

${ }^{49}$ Brunswick Corp. v. Pueblo Bowl-O-Mat, Inc., 429 U.S. 477 (1977) establishing the "antitrust injury" standard (that the plaintiff must have incurred the type of injury the antitrust laws specifically aim to protect) in antitrust standing.

${ }^{50}$ Edward C. Cavanaugh, "Illinois Brick: A Look Back and a Look Ahead", 17 Loyola Consumer Law Review 1, 2004, at 17; Gavil, supra note 2, at 865-66.

51 Illinois Brick, supra note 8, at 734-35.

52 Id.

${ }^{53}$ Id., at 736; Hanover Shoe, supra note 7, 494.
} 
indirect purchaser or he took part in the conspiracy, the relation between the indirect purchaser and the producer becomes essentially a direct one. ${ }^{54}$ In such cases, indirect purchasers can bring damages actions against the upstream producer. Likewise, in situations where the middleman supplies the product to the indirect purchaser on a cost-plus contract, it is deemed established that $100 \%$ of the overcharge is passed on to the indirect purchaser and therefore, the indirect purchaser can sue the upstream producer. Nevertheless, due to the Court's unwillingness to bring the analysis of possible lost sales of the middleman into damage calculation, the cost-plus contract exception applies only under strict conditions such as the existence of the contract before the conspiracy and purchase of the products of a fixed quantity determined by the contract. ${ }^{55}$ As these conditions hardly hold in the real world, indirect purchasers virtually cannot bring a damage action against violations of federal antitrust law. ${ }^{56}$

\section{Aftermath of Illinois Brick: The State Response to the Federal Policy and the Federal Indirect Purchaser Mess}

Needless to say Hanover Shoe and Illinois Brick caused an immediate public reaction and an intense debate within the antitrust community. Particularly consumer advocates who argue that the protection of consumer welfare should be the priority of antitrust policy were not pleased with the federal policy of denying compensation to final consumers. The year before Illinois Brick judgment was delivered, Congress had passed a bill granting the State Attorneys General ${ }^{57}$ parens patriae authority ${ }^{58}$ to claim damages on behalf of consumers. ${ }^{59}$ Clearly, with the indirect purchasers, including end users, denied standing in damage actions under federal antitrust law, that authority

\footnotetext{
${ }^{54}$ See ABA SECTION OF ANTITRUST LAW, INDIRECT PURCHASER LITIGATION HANDBOOK (hereinafter "ABA Handbook") (2007), at 18-19, 21.

${ }^{55}$ Id., at 16; compare Blue Shield of Virginia v. Carol McCready, 457 U.S. 464 (1982) to Kansas v. Utilicorp United, Inc. 497 U.S. 199 (1990).

${ }^{56}$ Herbert Hovenkamp, "The Indirect-Purchaser Rule and Cost-Plus sales", 103 Harvard Law Review 17171990.

${ }^{57}$ State Attorneys General are in very brief terms the chief legal officers of the states. They stand at the mainstream of state politics and fulfil political, administrative, law enforcement and quasi-legislative duties. See Firat Cengiz, "The Role of State AGs in the U.S. Antitrust Policy: Public Enforcement Through Private Enforcement Methods", ESRC Centre for Competition Policy, Working Paper No.06-19, available at http://www.ccp.uea.ac.uk/publicfiles/workingpapers/CCP06-19.pdf,

${ }^{58}$ Parens patriae is a common law doctrine which honours a sovereign's prerogative to protect those living under his rule. See Michael Malina, Michael D. Blechman, "Parens Patriae Suits for Treble Damages under the Antitrust Laws" (1970) 65 Northwestern University Law Review 193; George B. Curtis, "The Checkered Career of Parens Patriae: The State as a Parent or Tyrant?" (1975) 25 DePaul Law Review 895.

${ }^{59}$ Hart-Scott-Rodino Antitrust Improvements Act of 1976, Public Law 94-435; 15 U.S.C. §18(a).
} 
became at least partly redundant. Senators Hart, Scott and Rodino who were the sponsors of parens patriae bill immediately proposed another one for the overruling of Illinois Brick. ${ }^{60}$ During the thirty years which have passed since Illinois Brick, numerous other proposals have been unsuccessfully brought forward for changing the federal policy and the antitrust community has always continued to eagerly discuss other policy options. ${ }^{61}$

The strongest resistance to the federal policy came from the states, however. In the US, particularly industrialised states such as New York, California and Florida have a strong tradition of antitrust enforcement. In fact, some state antitrust statutes predate the federal ones. Additionally, protection of consumers through various mechanisms is a politically sensitive matter for most of the states. For instance, the State Attorneys General, who in most of the states are elected publicly, enjoy the authority to claim damages on behalf of the citizens in violations of both federal and state antitrust laws and they vastly publicise their successes in such efforts. On the other hand, states themselves may in certain instances be the victims of antitrust violations as they purchase products in order to fulfil their duties, and in such cases they generally stand as the indirect purchasers. For all these reasons, federal policy of eliminating indirect purchaser standing came into direct conflict with the state interests. As a response to Illinois Brick, the states turned to state laws, the most powerful weapon in their arsenal, and adopted Illinois Brick repealer statutes. To date twenty-four states, the District of Columbia and Guam, have adopted repealer statutes and four other states denied Illinois Brick through jurisprudence. ${ }^{62}$

\footnotetext{
${ }^{60}$ In fact to date various bills were introduced for the overruling of Illinois Brick but none of them managed to pass the Congress successfully. See e.g. H.R. 1942, 95 ${ }^{\text {th }}$ Cong., 2d Sess. (1978); S. 1874, 95 ${ }^{\text {th }}$ Cong., 2d Sess. (1978); H.R. 9132, $95^{\text {th }}$ Cong., $1^{\text {st }}$ Sess. (1977); H.R. 8516, $95^{\text {th }}$ Cong., $1^{\text {st }}$ Sess. (1977); H.R. 8359, $95^{\text {th }}$ Cong., 1st Sess. (1977); H.R. 2004, 96 ${ }^{\text {th }}$ Cong., $1^{\text {st }}$ Sess. (1979); H.R. 2060, 96 ${ }^{\text {th }}$ Cong., $1^{\text {st }}$ Sess. (1979); S. 300, 96 ${ }^{\text {th }}$ Cong., $1^{\text {st }}$ Sess (1979).

${ }^{61}$ For instance the American Bar Association published various reports where the current situation is criticised and alternative policy options are put forward. See "Report of the American Bar Association Antitrust Law Section Task Force on Legislative Alternatives concerning Illinois Brick Co. v. Illinois", 46 Antitrust Law Journal 1137 1997; "Report of the American Bar Association Section of Antitrust Law Task Force to Review Proposed Legislation to Repeal or Modify Illinois Brick", 52 Antitrust Law Journal 841 1983; "Report of the American Bar Association Section of Antitrust Law Task Force to Review the Supreme Court's Decision in California v. ARC America Corp.", 59 Antitrust Law Journal 273 (1990); "Report of the Indirect Purchaser Task Force, Section of Antitrust Law American Bar Association", 63 Antitrust Law Journal 9931995.

${ }^{62}$ ABA Handbook, supra note 54, at 26; Ralph Folsom, "Indirect Purchasers: State Antitrust Remedies and Roadblocks", Antitrust Bulletin, 50 (1), 2005, 181, at 182.
} 
Naturally, such conflict between the federal and state laws raised serious questions of federalism which were eventually brought before the Supreme Court in ARC America. ${ }^{63}$ In this case, the Court examined the validity of Illinois Brick repealers under the preemption doctrine. Preemption doctrine is the functional equivalent of the doctrine of supremacy of the Community law, but in practice is more tolerant of diversity compared to the doctrine of supremacy. In areas where the federal government is given the power of regulation by the Constitution, the Congress can preempt state law in the same area when adopting a bill by specifically and explicitly declaring its intention to do so. ${ }^{64}$ Likewise, in cases where the Congress did not declare its intention of preemption explicitly, state law is still deemed implicitly preempted if the Congress have regulated that area so pervasively as to leave no room for any further state regulation. ${ }^{65}$ Additionally, federal law preempts state law when the state law comes into direct conflict with the federal law in a way which makes it impossible for the subjects of the regulation to comply with the standards of both the state and federal laws at the same time ${ }^{66}$ or when it renders the accomplishment of congressional purposes virtually impossible. ${ }^{67}$ In the areas traditionally regulated by the states there is a presumption against finding preemption. ${ }^{68}$ Consequently, due to the existence of a strong tradition of antitrust regulation at state level, in ARC America the Court first observed that that presumption should be overcome in order to establish that the state Illinois Brick repealer statutes were preempted by the federal policy. ${ }^{69}$ Then, the Court clarified that there is neither express nor implicit congressional preemption in the field of antitrust policy as the state and federal statutes existed side by side since the emergence of the federal policy in this field. ${ }^{70}$ As it was not impossible for the subjects of the regulation to comply with the Illinois Brick doctrine and the state indirect purchaser statutes at the same time, the Court did not find conflict preemption either. ${ }^{71}$ And

\footnotetext{
${ }^{63}$ California v. ARC American Corporation (hereinafter "ARC America"), 490 U.S. 93 (1989).

${ }^{64}$ Id., at 100 .

${ }^{65}$ Pacific Gas \& Electric Co. v. State Energy Resources Conservation and Development Comm'n, 461 U.S. 190 (1983).

${ }^{66}$ Florida Lime \& Avocado Growers, Inc. v. Paul, 373 U.S. 132, 142-143 (1963).

${ }^{67}$ Hines v. Davidowitz, 312 U.S. 52 (1941); Silkwood v. Kerr-McGee Corp., 464 U.S. 238 (1984).

${ }^{68}$ Hillsborough County v. Automated Medical Laboratories, Inc., 471 U.S. 707 (1985).

${ }^{69}$ Citing Rice v. Santa Fe Elevator Corp., 331 U.S. 218, 230 (1947), ARC America, supra note 63 at 101.

${ }_{71}^{70}$ ARC America, id.

${ }^{71}$ Id., at 104.
} 
finally, the Court also observed that the state policy in this field did not stand as an obstacle to the accomplishment of Congressional intentions. In fact, according to the Court, federal and state policies aspired to the same end: "deterring anticompetitive conduct and ensuring the compensation of victims of that conduct." 72

After $A R C$ America, the American private enforcement regime turned to a chaotic environment where diverse standards regarding the passing-on defense and indirect purchaser standing coexist. Not only were federal and state policies regarding that matter different, but the standards of different states varied dramatically as well. For instance, whereas some states recognised standing of individual indirect purchasers, others gave the authority to their State Attorneys to bring cases on behalf of consumers. ${ }^{73}$ On the other hand, some states recognised the passing-on defense or any other mechanism in order to prevent multiple recoveries, whilst others recognised the standing of both indirect and direct purchasers. ${ }^{74}$ This immense diversity of federal and state standards resulted in a litigation disorder where the damage actions regarding same behaviour were brought before the federal and numerous state courts. For instance, the government proceedings under Sherman Act Section 2 against the monopolistic behaviour of Microsoft ${ }^{75}$ produced 64 federal and 117 state follow-on damage actions. Needless to say, in the lack of effective mechanisms for judicial cooperation, this chaotic litigation custom also raised the very real risks of inconsistent judgments delivered by federal and various state courts, possibly leading to multiple recoveries besides imposing significant litigation costs on the parties. ${ }^{76}$

Under American procedural law, cases brought before the state courts may be removed to a federal court to be consolidated with the related federal actions

\footnotetext{
${ }^{72} / d$.

${ }_{74}^{73}$ ABA Handbook, supra note 54 , at 26; Folsom, supra note 62.

${ }^{74}$ ABA, id.; Folsom, id.

${ }^{75}$ U.S. v. Microsoft, 231 F.Supp.2d 144 (D.D.C. 2002); New York v. Microsoft Corp., 209 F.Supp.2d 132 (D.D.C. 2002); New York v. Microsoft Corp., 224 F.Supp.2d 76 (D.D.C. 2002).

${ }^{76}$ Gavil, supra note 1, at 863; Ronald W. Davis, "Indirect Purchaser Litigation: ARC America's Chickens Come Home Roost on the Illinois Brick Wall”, 65 Antitrust Law Journal 375 1996, at 396; Jonathan T. Tomlin, Dale J. Giali,

"Federalism and the Indirect Purchaser Mess", 11 George Mason Law Review 157 2002, at 163; J. Thomas

Prud'Homme, Jr., Ellen S. Cooper, "One More Challenge for the AMC: Repairing the Legacy of the Illinois Brick", 40 University of San Francisco Law review 675 2005, at 676.
} 
only under two circumstances: first, when the state case involves a federal question, ${ }^{77}$ which is a priori not satisfied in indirect purchaser damage actions due to the opposite federal and state policies regarding that matter; ${ }^{78}$ and second, when diversity jurisdiction exists. In order for the diversity jurisdiction to exist, all of the class representatives must be of diverse citizenship from all of the defendants in terms of the state they reside in, and the class must satisfy the minimum amount in controversy requirement (currently more than $\$$ $75,000)^{79}$ - conditions which hardly hold in any indirect purchaser class action. On the other hand, possibility of coordination of various state actions is determined by the state procedural mechanisms which are as diverse as the state substantive standards. Under these circumstances, coordination of indirect and direct purchaser cases came to depend on voluntary cooperation between counsel of both sides of the controversy and efforts of the courts. In the past, parties and the courts entered into agreements for instance for the adjudication of pre-trial and trial phases before certain state courts and for the synchronization of proceedings before various state courts. ${ }^{80}$ Likewise, State Attorneys General, in cases which they brought on behalf of consumers, vigorously coordinated their activities through the mechanisms of National Association of State Attorneys General. ${ }^{81}$ Nevertheless, such voluntary mechanisms initiated only occasionally were not sufficient to ameliorate significant inefficiencies imposed by the mess of federal and state direct and indirect purchaser actions. Ironically, objectives which the Supreme Court embraced when designing the federal policy in Hanover Shoe and Illinois Brick were in the end totally destroyed.

Although this mess of litigation raised the litigation costs for everyone and therefore bruised the interests of both defendant-undertakings and plaintiffconsumers, these interest groups never managed to coalesce on which would

\footnotetext{
7728 U.S.C. 1367.

${ }^{78}$ Gavil, supra note 1 , at 870 .

${ }^{79} 28$ U.S.C. 1332 (a); see Ben-Hur v. Cauble, 255 U.S. 356 (1921); Zahn v. International Paper Co. 414 U.S. 291 (1973); Exxon Mobil v. Allapath Services, Inc., 125 Sup. Ct. 2511 (2005).

${ }^{80}$ Gavil, supra note 1, at 863; Cavanaugh, supra note 50, at 30; Prepared Statement of Michael I. Denger Before the Antitrust Modernization Commission Hearing Panel on "State indirect Purchaser Actions: Proposals for Reform", June 27 2005, http://www.amc.gov/commission hearings/pdf/Denger.pdf, at 12.

${ }_{81}$ See e.g. : FTC v. Mylan Labs, Inc. 99 F. Supp. 2d 1 (D.D.C. 1999); In re Buspirone Antitrust Litigation, 185 F. Supp. 2d 363 (S.D.N.Y. 2002); State of Ohio v. Bristol-Myers Squibb Co., No. 02-civ-01080 (D.D.C. 2002); In re Vitamins Antitrust Litigation, 320 F. Supp. 2d 1 (D. D.C. 2004) as examples of multi-state indirect purchaser actions litigated by the State AGs in a coordinated way.
} 
be the optimal policy to replace the existing one. ${ }^{82}$ Whereas the states and consumer groups advocated for the overruling of the Hanover Shoe and Illinois Brick doctrines, businesses naturally supported congressional preemption of state indirect purchaser statutes. As a result, no attempt for the policy change gained universal support and diverse federal and state standards continues to co-exist to date. The only development with a possible positive impact on the current status of the private enforcement regime was the passing of the Class Action Fairness Act $^{83}$ in 2005. This Act was not antitrust specific but aspired to coordination of federal and state class actions in all subject matters by loosening the conditions of removal of state cases to the federal courts particularly through diversity jurisdiction. ${ }^{84}$ However, the Act is not expected to make a dramatic change in the antitrust field due to the many exceptions it brings with it to the new standard of diversity jurisdiction. ${ }^{85}$ Perhaps more importantly, however, the Act does not harmonise diverse federal and state standards. ${ }^{86}$ In other words, even if various state cases are to be successfully consolidated with the federal ones before the same federal forum, they will continue to be adjudicated under diverse standards and, consequently, the risks of inconsistency and duplicative recoveries will remain intact.

\section{Antitrust Modernization Commission's Proposals and Lessons for the EC}

Blue ribbon commissions have regularly been formed in the US for sectoral or general revisions of the federal antitrust policy. ${ }^{87}$ The latest of such commissions, namely the Antitrust Modernization Commission, was founded in 2002 for the general assessment of the substantive as well as the procedural aspects of the US antitrust policy. ${ }^{88}$ Due to the current mess of indirect and direct purchaser litigations, the Commission decided at the outset

\footnotetext{
${ }^{82}$ Davis, supra note 76, at 390; Gavil, supra note 1, at 887; Prud'Homme, Cooper, supra note 76, at 676.

${ }^{83} 28$ U.S.C. $\S \S 1332(\mathrm{~d}), 1453$, and 1711-1715.

${ }^{84} 28$ U.S.C. § 1332 (d)(2); Professor William B. Rubenstein, UCLA Program on Class Actions, "Understanding the Class Action Fairness Act of 2005", available at http://www.classactionprofessor.com/cafa-analysis.pdf, at 2.

8528 U.S.C. $\S 1332$ (d)(4); 28 USC $\$ 1332(d)(3)$.

${ }^{86}$ Cavanaugh, supra note 50, at 47-48; AMC, Final Report, supra note 9, at 271; Testimony of Mark J. Bennett and

Ellen S. Cooper before the Antitrust Modernization Commission, June 17, 2005, available at

http://www.amc.gov/commission hearings/pdf/Bennett Cooper.pdf, at 15; Gavil, supra note 45, at 22.

${ }^{87}$ See Albert A. Foer, "Putting the Antitrust Modernisation Commission into Perspective", (2003) 51 Buffalo Law

Review 1029.

${ }^{88}$ Antitrust Modernization Commission Act of 2002, Pub. L. No. 107-273, §§ 11051-60, 116 Stat. 1856.
} 
to incorporate matters of passing-on defense and indirect purchaser standing into its agenda. Experts representing consumer as well as business interests and academic perspectives testified at the Commission's hearings. Although everyone agreed that the current situation was extremely inefficient and required an immediate solution, consensus regarding the ideal policy alternative to replace the current one was hard to reach. Whereas state and consumer perspectives argued for the overruling of Illinois Brick and Hanover Shoe and procedural mechanisms for the consolidation of all indirect and direct purchaser actions regarding the same violation before a single court, ${ }^{89}$ business representatives preferred overruling of state indirect purchaser statutes, but since that option had less than a little chance of passing the Congress due to political sensitivity, they offered a "wait and see" approach in general and argued that dramatic action should not be taken before it becomes clear whether the Class Action Fairness Act will successfully ameliorate the current mess of litigation. ${ }^{90}$

The Supreme Court and US antitrust community have always approached the matter of private enforcement almost exclusively from the perspective of effectiveness and efficiency. The Commission too followed this perspective and expressed in its final report that due to their superiority from these perspectives, the Hanover Shoe and Illinois Brick doctrines would represent the best policy options, if things were to be written on a "clean slate". ${ }^{91}$ Nevertheless, the bottom-up flexible federalist understanding of the US which respects diversity between the federal and state policy choices to the outmost extent had resulted in a total system failure in the matter of indirect purchaser damage actions. The current situation could best be described as a "lack of policy" at the federal level, as indirect purchasers get into the system through damage actions under the state laws anyway. ${ }^{92}$ Under these circumstances,

\footnotetext{
${ }^{89}$ Bennett, Cooper supra note 86; Denger, supra note 80, Gavil, supra note 45.

${ }^{90}$ ABA Section of Antitrust Law, Response to Antitrust Modernization Commission Request for Comment on Civil Remedies, June 12, 2006; Prepared statement of Jonathan W. Cuneo before the Antitrust Modernization

Commission, June 27, 2005, available at http://www.amc.gov/commission hearings/pdf/Cuneo rev2.pdf; Prepared Statement of Dan E. Gustafson before the Antitrust Modernisation Commission June 27, 2005, available at http://www.amc.gov/commission hearings/pdf/Gustafson.pdf; Margaret M. Zwisler , Testimony Before the Antitrust Modernization Commission, June 27, 2005, available at http://www.amc.gov/commission hearings/pdf/Zwisler.pdf; Written Testimony of David B. Tulchin Before the Antitrust Modernization Commission, available at http://www.amc.gov/commission hearings/pdf/Tulchin.pdf.

${ }_{91}$ AMC Final Report, supra note 9, at 266.

${ }_{92}$ Tomlin, Giali, supra note 76, at 157; Davis, supra note 76, at 396.
} 
damage actions regarding the same conduct were independently adjudicated by multiple courts at the expense of inconsistency, multiple recoveries and massive burdens on the judicial economy. ${ }^{93}$ And as a result, the Hanover Shoe and Illinois Brick doctrines raised impediments to the efficiency and effectiveness of the private enforcement regime rather than contributing to these goals.

In order to cure the disease, federal and state standards should be harmonised and procedural mechanisms should be adopted for the adjudication of all indirect and direct purchaser actions relating to the same conduct in a coherent way. ${ }^{94}$ Although preemption of state indirect purchaser statutes by the federal law would be the most obvious method of harmonisation, this option was rejected almost immediately as it raised serious questions of federalism and state autonomy and therefore had almost no prospect of passing the Congress. ${ }^{95}$ Consequently, as a second best option, the Commission proposed a package of proposals consisting of:

1) Overruling of Illinois Brick through legislative action to the extent necessary for compensation of indirect purchasers under federal law,

2) Overruling of Hanover Shoe through legislative action to the extent necessary for the prevention of multiple recoveries,

3) Adoption of mechanisms for the removal of state indirect purchaser actions to the federal courts and consolidation of all indirect and direct purchaser damage actions regarding the same conduct before the same federal forum. ${ }^{96}$

If this proposal passes the Congress successfully, indirect purchasers will be entitled to bring actions for damages before the federal courts under federal law and state indirect and direct damage actions may be removed to the federal courts for consolidation with the federal cases regarding the same violation. The passing-on defense will be allowed and once the liability is established damages will be apportioned amongst different clusters of

\footnotetext{
${ }^{93}$ AMC Final Report, supra note 9, at 271.

${ }^{94} \mathrm{ld}$.

${ }_{95} / d$., at 274.

${ }^{96}$ ld., at 267.
} 
defendants depending on how much of the overcharge is passed-on. As a result, burdens imposed on the judicial economy by multiple actions regarding the same conduct and the threats of inconsistent judgments and multiple recoveries will be eliminated. There are serious doubts as to whether the Commission's proposals will be introduced to the Congress, let alone pass the Congress successfully and become binding law. It has been argued that these proposals were "dead on arrival" as they represent too dramatic a policy change. ${ }^{97}$ Additionally, there have always been serious disagreements amongst different interest groups regarding the ideal federal policy of indirect purchaser actions and there was no reason to believe that a coalition will be formed between those interests this time. ${ }^{98}$ In fact, even the Commissioners were split amongst themselves and wrote separate reports on some issues. ${ }^{99}$ Their chance of actually changing current federal policy aside, it is still worth considering whether the European Community could draw any policy lessons from at least the history and rationales behind the Commission's ambitious proposals. The Commission's initiative for a federal policy reform did not stem from a dissatisfaction with the current policy in the substantive sense. On the contrary, current policy appears perfectly compatible with the dominant American vision which perceives private enforcement as a mechanism of deterrence rather than compensation. There is a dramatic contrast between this vision which restricts access of individuals to redress for the sake of effectiveness and the European doctrine of direct effect. The European Court of Justice's jurisprudence established that Community law does not only impose obligations on Member States but also enshrines directly effective rights of individuals constitutes one of the core foundations of European legal regime. ${ }^{100}$ Directly effective rights of individuals are exercised mainly through actions before the national courts and other national institutions responsible for enforcing Community law. In order to sustain effective and consistent enforcement of such directly effective rights, the European Court of Justice

\footnotetext{
${ }^{97}$ Richman, Murray, supra note 10, at 22.

${ }^{98}$ ld.

${ }^{99}$ See Separate Statement of Commissioners Burchfield, Delrahim, Jacobson, Kempf, Litvack, Valentine, and Warden; Separate Statement of Commissioner Carlton; Separate Statement of Commissioner Delrahim; Separate Statement of Commissioner Jacobson, Joined by Commissioner s Valentine (Except as to Part III) and Warden (Except as to Parts I.B and II.B); Separate Statement of Commissioner Kempf; Separate Statement of Commissioner Shenefield; Separate Statement of Commissioner Warden, all attached to the AMC Final Report, supra note 9, at 395-449.

${ }^{100}$ C-26/62 Van Gend en Loos v. Nederlandse Administerarie der Belstigen [1963] ECR I.
} 
innovated various mechanisms under the duty of loyalty of Member States which is enshrined in Article 5 (now 10) EC. Those mechanisms most notably contain the principles of equivalence and effectiveness ${ }^{101}$ and the monetary liability of Member States for breaches of Community law. ${ }^{102}$ In other words, similar to the American jurisprudence, effectiveness constitutes one of the main rationales behind the jurisprudence of the European Court of Justice regarding the enforcement of Community law. Nevertheless, American and European understandings of effectiveness are significantly different. Whereas in the understanding of Supreme Court effectiveness mainly refers to deterrence of breaches of federal law through strategic design of enforcement regime, European Court of Justice perceives effectiveness as consistent and almost absolute enforcement of the rights stemming from Community law across time and in different Member States. As it will be seen in the following part of this Paper, right of the individuals to access redress against the violations of Articles 81 and $82 \mathrm{EC}$ does not represent an exception to this philosophy. ${ }^{103}$ Needless to say, under the European understanding of effectiveness, it would be extremely hard if not impossible to justify restriction of a class of individuals' rights to bring actions for damages against the violations of Community competition law for the sake of deterrence. For these reasons, transatlantic policy learning regarding the issues of indirect purchaser standing and passing-on defense in the substantive sense does not seem possible.

However, the US experience is very informative and offers valuable lessons in terms of complexities and complications a private enforcement regime will have to face in the presence of multiple diverse standards and in the lack of effective cooperation mechanisms between the courts that enforce those

\footnotetext{
101 "....in the absence of Community rules governing the matter, it is for the domestic legal system of each Member State to designate the courts and tribunals having jurisdiction and lay down the detailed procedural rules governing actions for safeguarding rights which individuals derive directly from Community law, provided that such rules are not less favourable than those governing similar domestic actions (principle of equivalence) and that they do not render practically impossible or excessively difficult the exercise of rights conferred by Community law (principle of effectiveness).", see C- 33/76 Rewe v Landwirtschaftskammer fuer das Saarland [1976] ECR 1989, para. 5; C-45/76 Comet v Produktschap voor Siergewassen [1976] ECR 2043, paras. 12-16, C- 68/79 Hans Just v Danish Ministry for Fiscal Affairs [1980] ECR 501, para. 25, C-199/82 Amministrazione delle Finanze dello Stato v San Giorgio [1983] ECR 3595, para. 14.

${ }_{102}$ C-6 \&9/90, Francovich and Bonifaci v. Italy [1991] ECR I-5357; C-46 \&48/93, Brasserie du Pêcheur SA v Bundesrepublik Deutschland and The Queen $v$ Secretary of State for Transport, ex parte: Factortame Ltd and others. ${ }^{103}$ See Courage infra text to note 104 et seq. Also the rules of competition enjoy constitutional status in the EC whereas the Sherman and Clayton Acts do not go beyond being pieces of ordinary national legislation in the US. And this essential difference naturally suggests that the standing could not possibly be restricted in the EC to the extent that it is in the US under the Illinois Brick doctrine. See Clifford A. Jones, Private Enforcement of Antitrust Law in the EU, UK and USA, Oxford University Press, Oxford New York, 1999, at 187, 191.
} 
standards. Had the federal and state standards regarding the issues of passing-on defense and indirect purchaser standing been compatible with each other or alternatively had there been cooperation mechanisms between the federal and state courts for the litigation of all of the cases relating to the same violation either before a single legal forum under a single standard or by various courts in cooperation, substantive policy change at the federal level would probably not prove necessary. In other words, US experience regarding passing-on defense and indirect purchaser standing clearly illustrates that in a multi-level polity either harmonised standards across the constituent units or solid mechanisms of cooperation amongst the courts applying those standards are inevitable for an effective private enforcement regime to exist. Otherwise, no matter how plausibly designed any substantive policy option will become practically unenforceable.

\section{Passing-on defense and Indirect Purchaser Standing in Europe: Current Position of Community Law and Proposals for Future Direction}

It is questionable whether a common policy regarding the issues of indirect purchaser standing and passing-on defense currently exists in Europe. European Court of Justice touched upon these subjects various times without going into the specifics and setting forth clear rules. For instance, in Courage $^{104}$ the Court was asked whether an individual who had been party to an agreement violating Community competition rules should be entitled to damages. In response, the Court first repeated its stare decisis that Articles 81 and 82 EC "produce direct effects in relations between individuals and create rights for the individuals concerned which the national courts may safeguard". ${ }^{105}$ And then, it ruled that:

"The full effectiveness of Article 85 of the Treaty and, in particular, the practical effect of the prohibition laid down in Article 85(1) would be put at risk if it were not open to any individual to claim damages for the loss caused to him by a

\footnotetext{
${ }_{104}^{104}$ C-453/99 Courage Ltd v Bernard Crehan, ECR [2001] I-6297.

${ }^{105}$ ld., at 23.
} 
contract or by conduct liable to restrict or distort competition." 106 (Emphasis added.)

As the Court specifically mentioned that any individual should be able to obtain damages suffered as a result of violations of Community law in exercise of his directly effective rights, it may be argued that the Courage formula implicitly requires granting of standing to indirect as well as direct purchasers in actions for damages against violations of Community competition law. However, there is a consensus that in Courage the Court did not intend to produce any kind of principles affecting the national standing rules, ${ }^{107}$ but it simply repeated the general principle of direct effect which was first applied in the context of Community competition law in BRT Sabam. ${ }^{108}$

A few years later, in Manfedi, ${ }^{109}$ the Court was asked this time specifically whether the principle of direct effect requires granting of standing to indirect purchasers against the violations of Community competition law. In this case, the Italian Court asked whether individuals who purchased motor insurance from insurance brokers and agents should be entitled to bring damage actions against the insurance companies who were found to operate a price-fixing cartel in violation of Article 81 EC. In its response to this question, the Court first repeated BRT Sabam and Courage formulae that as a requirement of the principle of direct effect it must be open to any individual to exercise his rights under Community law to the full extent, ${ }^{110}$ and then ruled that "...any individual can claim compensation for the harm suffered where there is a casual relationship between the harm and agreement or practice prohibited under Article 81 EC." 111 In other words, the Court ruled that in principle there should be no legal obstacle hindering actions for damages by indirect purchasers; however, it ultimately was for the national courts to decide under

\footnotetext{
106 Id. at 26.

${ }^{107}$ Norbert Reich, "Horizontal Liability in EC Law: Hybridization of Remedies for Compensation in case of breaches of EC Rights", Common Market Law Review 44(3) 705-742, 2007, at 719; Ulf Boge, Konrad Ost, "Up and Running, or is it? Private Enforcement - The Situation in Germany and Policy Perspectives", European Competition Law Review 2006, 27(4), 197-205, at 200-201; Commission of the European Communities, Commission Staff Working Paper, Annex to the Green Paper, Damages Actions for Breach of the EC Antitrust Rules, Brussels, 19.12.2005, Sec (2005) 1732, available at http://ec.europa.eu/comm/competition/antitrust/actionsdamages/sp en.pdf, at 47, para. 165.

108 See C-127/73 Belgische Radio en Televisie v SV SABAM and NV Fonior [1974] ECR 51, para. 16.

${ }^{109}$ C-295/04 Vincenzo Manfredi v Lloyd Adriatico Assicurazioni SpA, ECR [2006] I-06619.

110 Id., at 60.

${ }^{111}$ Id., at 61 .
} 
the national rules on causality who will enjoy standing. It is questionable whether Manfredi creates a Community-wide right of standing for indirect purchasers. As the Court neither mentioned the concept of indirect purchasers nor went into the specific aspects of the matter in its reasoning, it appears that Manfredi corresponds more to a repetition of a general principle of Community law in a specific field rather than declaration of a universal right. In that sense, the Court showed deference to national procedural autonomy and threw the ball back to national courts who would conduct the analysis under their national laws and consequently be free to reject indirect purchaser standing under the rules of causality, for instance when the harm proves to be too remote from the conduct from the perspective of national law.

The position of Community law regarding passing-on defense is no less complicated. The Court faced the question as to whether passing-on defense exists under Community law directly in cases regarding the extra-contractual liability of the Community and liability of the Member States in breaches of Community law and indirectly in damage actions against violations of Community competition law. In cases regarding extra-contractual liability of the Community under Article 288 (ex Article 215) EC, the Court implicitly recognised a passing-on defense in various cases, analysed detailed statistical pricing data, and ruled to what extent the plaintiff had passed the damages on to consumers before deciding on the damage award. ${ }^{112}$ Some authors argued that the Court's jurisprudence in the field of extra-contractual liability of the Community implies existence of a universal passing-on defense under Community law. ${ }^{113}$ Nevertheless, extra-contractual liability of the Community is based on the principles which are explicitly and directly set forth by the founding Treaty. The Court of Justice enjoys exclusive jurisdiction in litigation of conflicts regarding this matter and national laws do not come into play unless the Court faces a legal gap in Community law and calls for the cooperation of general principles of national laws in filling such gap. On the

\footnotetext{
${ }^{112}$ See e.g. Dumortier Freres SA and Others v Council of the European Communities (Maize Gritz Cases) joined cases 64, 113/76; 239/78; 27, 28, 45/79 ECR [1979] 3091; C-238/78 Ireks-Arkady GmbH v Council and Commission of the European Communities (Quellmehl Cases) ECR [1979] 2955.

${ }^{113}$ Thomas Eilmansberger, "The Green paper on Damages Actions for Breach of the EC Antitrust Rules and Beyond: Reflections on the Utility and Feasibility of Stimulating Private Enforcement Through Legislative Action", Common Market Law Review, 2007, 44:431-478, at 474; Reich, supra note 107, at 712; See also Opinion of Mr Advocate General Van Gerven, H.J. Banks \& Co. Ltd v British Coal Corporation ECR 1994 I-1209.
} 
other hand, although stemming from a directly effective Community right, cases regarding breaches of Community competition law are nevertheless litigated before the national courts under national substantive and procedural standards. In other words, extra-contractual liability of the Community does not involve very sensitive question of national procedural autonomy and therefore stands on very different dynamics from those of the actions for damages against the breaches of Community competition law. As a result, it does not seem possible let alone plausible to transfer the principles created to be applied within the field of Community liability to the sphere of liability of individuals for breaches of Community competition law. Likewise, in the past the Court faced questions of passing-on in cases regarding the liability of Member States for breaches of Community law. ${ }^{114}$ In such cases, the Court implicitly recognised that such a defense exists but left it to the national courts to decide on whether pass-on had actually happened in the specific cases in question. Although being adjudicated by the national courts, liability of Member States for breaches of Community law does not only stem from a directly effective Community law but also the very specific objective and subjective conditions of the exercise of such right, such as causality and fault, are firmly determined by the Court's jurisprudence. ${ }^{115}$ In other words, the same caveat as in the field of the extra-contractual liability of the Community applies here, and principles developed within the field of liability of Member States cannot shed light on the position of the Community law regarding the specific aspects of actions for damages against violations of Community competition law.

The issue of passing-on defense was never raised specifically within the context of damage actions against violations of Community competition law. But the Court addressed a similar question, a question regarding the possibility of unjust enrichment of the plaintiff as a result of the damage award in Courage and Manfredi. In Courage as the plaintiff was a party to the agreement, the Court was asked whether it would be against Community law if the plaintiff had been rejected damages under the principles of bona fide of

\footnotetext{
${ }^{114}$ See e.g. C-192/95 Societe Comateb v Directeur General Des Douanes et Droits Indirects ECR [1997] I-165; Joined Cases C-441-42/98 Kapniki Michailidis AEv Idryma Koinonikon Asfaliseon (IKA) ECR Reports 2000 I-7145.

${ }^{115}$ See Francovich and Brasserie Factortame, supra note 102.
} 
national law. Again, as in the matter of indirect purchaser standing, the Court showed deference to national autonomy and ruled that as long as the principles of effectiveness and equivalence are respected, "Community law does not prevent national courts from taking steps to ensure that the protection of the rights guaranteed by the Community law does not entail the unjust enrichment of those who enjoy them."116 Later, the Court repeated the same formula in Manfredi. ${ }^{117}$ Matters of unjust enrichment and passing-on defense are essentially similar in terms of their underlying rationales. They both stem from the fairness consideration, albeit one deals with the question whether an individual should be entitled to damages under conditions which do not fully justify such damage award, and the other whether an individual should be entitled to damages he did not actually incur. The only practical difference is that analysis of passing-on proves much more complicated than that of unjust enrichment as it involves technical economic and econometric data. That difference aside, it is not hard to imagine that the Court's position would not be dramatically different in the matter of passing-on defense from its position regarding unjust enrichment.

It follows that Community law as developed so far does not foresee any specific and clear principles regarding indirect purchaser standing and passing-on defense but it leaves these matters largely to the national laws as long as those laws comply with the principles of effectiveness and equivalence. The Ashurt study on the conditions of damage actions in Europe revealed that in the vast majority of Member States both indirect purchaser standing and passing-on defense appears possible at least theoretically, although in most of the Member States there had been no specific court decisions regarding these issues so far. ${ }^{118}$ Passing-on defense has explicitly been recognised by the Danish and Italian Courts and some regional courts in Germany. ${ }^{119}$ In terms of indirect purchaser actions, the study revealed that in jurisdictions where a direct causal link between the harm and actions is required, such as Austria, Cyprus, Ireland, Italy, Luxembourg and Malta,

\footnotetext{
${ }^{116}$ Courage, supra note 104 , at 30.

${ }^{117}$ Manfredi, supra note 109 , at 94.

${ }_{118}$ Comparative Report, supra note 4, at 6.

${ }^{119}$ Id., at 79.
} 
standing could become problematic. ${ }^{120}$ On the other hand, under the "protective purpose of the norm" theory (Schutznormtheorie), national courts in Germany and Austria demanded in the past that the "plaintiff be a person or belong to a definable group of persons against whom the infringement has specifically been directed". ${ }^{121}$ For instance, under this theory, German courts rejected the claims by indirect purchasers against the members of international vitamins cartel, whereas the English court accepted such claims. ${ }^{122}$ In 2005 very specific rules regarding the damage actions were adopted with the $7^{\text {th }}$ amendment to the German Act against Restraints of Competition (Gesetz Gegen Wettbewerbsbeschränkungen- GWB). Under the new rules, lower courts seemed to be inclined to accept passing-on defense whereas the dominant view in the antitrust community supports rejection of such defense due to efficiency considerations. ${ }^{123}$ Likewise, after the amendment, indirect purchaser standing does not seem realistic as the German law grants standing only to persons from the opposite side of the market directly affected by the violation in question. ${ }^{124}$

In summary, Community law appears to have left determination of the standards regarding indirect purchaser standing and passing-on defense to the national laws to a large extent. These issues have not been directly and decisively determined by the national courts yet either, but the current evidence suggests that there is certain room for diversity between different national standards. The economic literature does not offer a concrete conclusion as to whether indirect or direct purchasers prove more effective plaintiffs. Likewise there still is no solid empirical evidence regarding the effects of Illinois Brick doctrine on the effectiveness of federal antitrust policy in the US. Under these conditions, there seems to be no convincing reason justifying compromising of fairness for the sake of effectiveness. From this

\footnotetext{
${ }^{120}$ Id., at 78.

121 ld., at 38.

122 Mainz District Court, decisions of January 15, 2004, Cases 12 HK.O 52/02, 12 HK O 55/02 and 12 HK O 56/02, published in NJW-RR 2004, 478; Mannheim District Court, decision of July 11, 2003, Case 7 O 326/02, published in GRUR 2004, 182; Karlsruhe Court of Appeal, decision of January 28, 2004, Case 6 U 183/03, published in WuW DER 1229, all cited in Cedric Ryngaert, "Foreign-to-Foreign Claims: the US Supreme Court's Decision (2004) v the English High Court's decision (2003) in the Vitamins case (Case Comment)", European Competition Law Review, 2004, 25(10), 611-616, at 615. Compare to Provimi Ltd v Aventis Animal Nutrition SA; Trouw (UK) Ltd v Rhodia Ltd, Provimi Ltd v Roche Products Ltd, Trouw (UK) Ltd v Roche Products Ltd, [2003] 2 All E. R. (Comm.) 683.

${ }_{123}$ Boge and Ost, supra note 107, at 200.

124 Id., at 200-201.
} 
perspective, the last option amongst the policy proposals put forward by the Commission's Green Paper, which foresees a two-step procedure where both the indirect and direct purchasers can sue and where damages are apportioned between the two classes in the second phase of litigation, ${ }^{125}$ appears as the ideal option, as it provides access to redress to all clusters of plaintiffs without giving way to any windfall effects albeit at the expense of compromising efficiency of litigation. In fact, this policy option resembles quite closely the Antitrust Modernization Commission's proposal which was put forward after three decades of indirect and direct purchaser litigation experience.

However, a question to be answered in the first place when it comes to private enforcement of Community competition law is whether harmonisation of national standards in this field is necessary and desirable, rather than what would be the best policy option in the case of harmonisation. With the White Paper on private enforcement yet to come, at this stage there is no concrete evidence regarding the Commission's intentions. In fact the Commission itself declared quite frankly that it has not yet reached a final conclusion regarding the strategy which it will follow in order to facilitate private enforcement in Europe. ${ }^{126}$ However, there is currently evidence that if the Commission decides to take the path of harmonisation of national standards, it will have to face a strong resistance from the national level. For instance, both the Office of Fair Trading and the Bundeskartellamt emphasised in their responses to the Green Paper that harmonisation of national standards would be a disproportionate intrusion to national autonomy incompatible with the principle of subsidiarity, and there certainly is no need for such a drastic action for facilitation of private enforcement. ${ }^{127}$ Consequently, harmonisation of national standards in this field in the near future does not seem very realistic.

\footnotetext{
${ }^{125}$ Green Paper, supra note 5, Option 24.

${ }^{126}$ European Commission Press Release, "Competition: Commission launches consultations on facilitating damages claims for breaches of EU competition law", IP/05/1634, Brussels, $20^{\text {th }}$ December 2005, available at http://europa.eu/rapid/pressReleasesAction.do?reference=IP/05/1634\&format=HTML\&aged=0\&language=EN\&guiLa nquage $=$ en.

${ }^{27}$ Office of Fair Trading, Response to the European Commission's Green paper, Damages Actions for Breach of the EC Antitrust Rules, May 2006, available at

http://www.oft.gov.uk/shared oft/reports/oft response to consultations/oft844.pdf, at 2, para. 2.2; Comments of the Federal Ministry of Economics and Technology and the Federal Cartel Office on the Green paper of the EU

Commission, available at http://www.oft.gov.uk/shared oft/consultations/Private-responses/BundesKartellamt.pdf, at $1-2$.
} 
The US experience of indirect and direct purchaser actions for damages under diverse standards stands as a lesson that under such diversity strong mechanisms for cooperation amongst the judiciary must exist, otherwise the system will have to face a major failure. In order to avoid such a system failure, related cases should be litigated either under a single set of standards before a single legal forum or before multiple forums in a coordinated way. Although the issue of judicial cooperation is closely connected to national procedural standards and therefore to national procedural autonomy, since the foundation of the European Communities, consistent application of Community law through vigorous judicial cooperation was perceived as a vital element of the freedom of movement and therefore actions were taken at the Community level in order to facilitate such cooperation to the full extent. At first, Article 220 of the Treaty founding the European Economic Community provided the opportunity for the Member States to enter into agreements with each other regarding judicial cooperation, although leaving the matter entirely to their discretion, and Member States exploited that opportunity with the enactment of the Brussels Convention on Jurisdiction and the Enforcement of Judgments in Civil and Commercial Matters in 1968. Later on, the Treaty founding the European Union provided specific provisions regarding enactment of measures in the field of judicial cooperation in civil matters having cross-border implications, and the Amsterdam Treaty transferred those provisions to the EC pillar. ${ }^{128}$ In the 1999 Tampere Summit, the European Council reiterated the goal of creating a Union of freedom, security and justice and firmly established that action would be taken at the Community level to facilitate judicial cooperation as a means of achieving this goal.. ${ }^{129}$ Consequently, in 2001 the Brussels Regulation on Jurisdiction and the Recognition and Enforcement of Judgments in Civil and Commercial Matters (Brussels I) ${ }^{130}$ superseding the 1968 Brussels Convention was adopted. This Regulation also applies to conflicts arising out of violations of Community competition law. Likewise, the Regulation on the Law Applicable to Non-

\footnotetext{
${ }^{128}$ Article 65 EC et seq.

${ }^{129}$ Tampere Council, 15-16 October 1999, Presidential Conclusions, available at http://www.europarl.europa.eu/summits/tam en.htm.

${ }^{130}$ Council Regulation (EC) No 44/2001 of 22 December 2000 (hereinafter "Brussels I"), 16.1.2001 OJ L 12/1.
} 
Contractual Obligations (Rome II) ${ }^{131}$ which was adopted in July 2007 sets forth rules of conflict of laws applicable inter alia to private actions for damages against violations of Community competition law. Both Regulations codify general principles of procedural law which are inherent in all of the Member States' legal traditions.

As a general rule, Brussels I Regulation determines domicile of the defendant as the main forum of jurisdiction. ${ }^{132}$ However, there are alternative rules of jurisdiction which may come into play in conflicts regarding the breaches of Community competition law. For instance, in matters of tort, delict or quasidelict, the courts where the harmful event occurred, or may occur, enjoy alternative jurisdiction. ${ }^{133}$ European Court of Justice interpreted this provision in a quite liberal manner in the past and ruled that it confers jurisdiction to courts of the place where the damage occurred as well as courts of the place where the event giving rise to it took place. ${ }^{134}$ Additionally, in Member States where criminal remedies are imposed on violations of competition law, the criminal court seised may enjoy jurisdiction over the damage claims arising out of the violation to the extent that national law gives jurisdiction to such court over commercial and civil matters. ${ }^{135}$ Likewise, in disputes regarding operations of a branch, agency or other establishment, undertakings may be sued in places where such branch, agency or establishment is situated. ${ }^{136}$ Last but not least, where he is one of the defendants, a person may be sued in courts of the place where any of the defendants resides provided that the claims are so closely connected that it is expedient to hear and determine them together to avoid the risk of irreconcilable judgments resulting from separate proceedings. ${ }^{137}$ Considering that, most of the time, violations of the Community competition law affect multiple markets and involve various coconspirators, branches and subsidiaries, it is not hard to imagine that under these rules of jurisdiction, a potential medium scale violation will give rise to

\footnotetext{
${ }^{131}$ Regulation (EC) No 864/2007 of the European Parliament and of the Council of 11 July 2007 (hereinafter "Rome II") L 199/40 OJ 31.7.2007.

${ }_{132}$ Brussels I, supra note 130, Article 2(1).

${ }^{133} / d$., Article 5(3).

${ }^{134} \mathrm{C}-21 / 76$, Handelskwekerij G. J. Bier BV v Mines de potasse d'Alsace SA ECR [1976] 1735, at para.11.

${ }^{135}$ Brussels I, supra note 130, Article 5(4).

${ }^{136}$ Id., Article 5(5).

${ }^{137}$ Id., Article 6(1).
} 
various actions brought by consumers and competitors in different national markets before multiple national courts.

The Regulation also foresees rules regarding lis pendens in order to facilitate coherency and consistency of Community law in cases where closely connected actions are brought before various national courts. Nevertheless those rules give exclusive jurisdiction to the courts first seised only in cases of actions involving the same parties and the same cause of action. ${ }^{138}$ Apart from that, courts enjoy discretion to decline jurisdiction in favour of the court first seised when actions litigated before multiple courts are "so closely connected that it is expedient to hear and determine them together to avoid the risk of irreconcilable judgments resulting from separate proceedings". 139 As potential actions regarding violations of Community competition law will probably involve different plaintiffs located in different member states, the rules of lis pendens do not solve the potential problem of multiple courts adjudicating related actions under different standards.

It is the central argument of this paper that in order to avoid the mess of indirect and direct purchaser damage actions which caused a system failure in the US, either a single forum should be given jurisdiction to litigate connected cases under a single set of standards or multiple courts do so in cooperation. After this short review of the rules of jurisdiction, it becomes obvious that the first proposal does not hold in the Community. The question which follows is whether it is desirable to amend the rules of jurisdiction in order to confer exclusive jurisdiction to a single court in violations of Community competition law. It certainly is not. First of all, rules of jurisdiction codified in the Brussels I Regulation arise from the principles inherent in the legal traditions of Member States which embrace a balance between different interests. ${ }^{140}$ They all aim on the one hand to give priority to the interests of the legally or economically weak party of the dispute and, on the other hand, appoint the court of the

\footnotetext{
${ }^{138} / d$., Article 27.

${ }_{139}^{13}$ Id., Article 28(3).

${ }^{140}$ Janet A. Pontier, Edwige Burg, EU Principles on Jurisdiction and Recognition and Enforcement of Judgments in Civil and Commercial Matters, TMC Asser Press, The Hauge 2004, at 117, 124; Fausto Pocar, "Commentary on Brussels I Regulation", in Council of the European Union, Civil Law, European Judicial Cooperation, 2004, General Secretariat of the Council, 9-25, at 14.
} 
place with the closest geographical link to the dispute. ${ }^{141}$ Additionally, actions for damages against the violations of competition law has a strong fairness aspect which aims to make good any harm done to consumer welfare, and certainly dragging the consumer-plaintiffs located in different Member States before a single national court would significantly jeopardise that aim.

This leaves litigation of related actions by multiple state courts in coordination and under a single set of standards as the only policy option in order to avoid the mess of litigation which arose in the US. The Rome II Regulation on the conflict of laws foresees a special provision regarding the actions arising out of violations of Community competition law. According to that provision, in such cases, the law of the country where the market is, or is likely to be affected, applies. ${ }^{142}$ Naturally, any violation of Community competition law potentially affects multiple markets as in the first place it should have an impact on the trade between member states under Articles 81 and 82 EC for the Community competition law to apply. Under these circumstances, Community rules of conflict of laws allow litigation of actions brought against the same violation under standards of multiple national laws. In order to prevent inconsistent judgments regarding the same violation and multiple recoveries which seriously disturbed the dynamics of US private enforcement regime, Community rules of conflicts of laws should be reconsidered and if possible amended so as to allow application of only a single national standard in actions for damages against the violations of Community competition law. Work allocation rules of the European Competition Network which, albeit through soft-law measures and subject to the discretion of the national authorities, determine allocation of specific cases amongst national competition authorities, could be taken as a model to achieve this end. ${ }^{143}$ Following this model, laws of the Member State which sits at the centre of the

\footnotetext{
${ }^{141}$ Pontier, Burg, id:; Pocar, id.

142 Rome II Regulation, supra note 131, Article 6(3)(a). According to Article 6(3)(b) in cases where multiple national laws get involved, plaintiff has the choice to employ lex fori (the law of the forum) instead, provided that the forum is the domicile of the defendant and amongst the markets affected by the violations. However, multiple defendants are likely to bring multiple cases in multiple forums, this provision falls short of solving the problem.

${ }^{143}$ See Commission Notice on cooperation within the Network of Competition Authorities (hereinafter "Commission Notice"), 27.4.2004 OJ C 101/43, 2.1.: "Principles of Allocation".
} 
violation in question, in other which has the closest contact with the violation, could be given priority in cases where multiple national laws come into play. ${ }^{144}$ Effective judicial cooperation in cross-border litigation constitutes the other pillar of the proposal brought forward by this Paper. Smooth operation of cross-border litigation was amongst the top priorities of the Community since the Tampere Council. In order to achieve this aim, the Council adopted measures regarding assistance and exchange of information between the national courts. ${ }^{145}$ These measures enable national courts to exchange judicial and extra-judicial materials, collect evidence including witness depositions on behalf of each other and exchange such information through central receiving and transmitting authorities appointed by the Member States. Additionally, in order to facilitate direct communication amongst the national courts, in 2001 the Council adopted a decision establishing a judicial network in civil and commercial matters. ${ }^{146}$ This network composes of contact points designated by the Member States ${ }^{147}$ and is entrusted with the task of facilitating judicial cooperation and smooth operation of cross-border litigation. ${ }^{148}$ In its report regarding the progress of network in its first five years of operation, the Commission found that the "network facilitated judicial cooperation between courts in the Union and cut the time taken to process requests via its system of direct relations between the contact points." 149 These measures allow national courts to exchange information and evidence regarding the violation in question including witness evidence and consequently contribute to collective adjudication of cross-border litigation to a certain extent. However, European Judicial Network appears at an embryonic stage and mechanisms it entails seem inadequate for the litigation of damage actions collectively by multiple national courts. In that sense there certainly is room for improvement. Again, cooperation mechanisms which the European Competition Network entails may be taken as a model in the design of judicial

\footnotetext{
${ }^{144}$ Id., para.8.

${ }^{145}$ Council Regulation (EC) No 1348/2000 of 29 May 2000 on the Service in the Member States of Judicial and Extrajudicial Documents in Civil or Commercial Matters, 30.6.2000 OJ L 160/37; Council regulation (EC) No 1206/2001 of 28 May 2001 on Cooperation between the Member States in the Taking of Evidence in Civil or Commercial matters, 27.6.2001 OJ L 174/1.

${ }^{146}$ Council Decision of 28 may 2001 establishing a European Judicial Network in Civil and Commercial matters, 27.6.2001 OJ L 174/25.

147 Id., Article 2(1).

${ }^{148}$ Id., Article (3).

${ }^{149}$ Report from the Commission to the Council, the European Parliament and the European Economic and Social Committee on the Application of Council Decision 2001/470/EC establishing a European Judicial Network in Civil and Commercial Matters, Brussels, 16.5.2006 COM(2006) 203 final, at 5.
} 
cooperation. For instance, the lead authority mechanism whereby multiple competition authorities conduct joint investigation of the same or related violations under the coordination of a single could set an example for judicial coordination in litigation of closely related damage actions. ${ }^{150}$

In summary, there already is a strong foundation of Community measures which aim to smooth cross-border litigation and apply inter alia to damage actions against violations of Community competition law. When it comes to the specific proposals of this Paper, rules of jurisdiction seem to raise discrepancies as they potentially appoint multiple national courts for litigation of related cases. However, due to procedural dynamics and fairness considerations, it is not as desirable to amend those rules as to adopt more stringent ones at this stage. On the other hand, rules of conflict of laws and judicial cooperation have considerable potential of facilitating litigation of closely connected cases by various national courts, albeit with certain room for improvement. The rules of conflict of laws should be amended to allow employment of a single set of standards in actions brought by different plaintiffs in different national courts against the same violation, and measures which the European Judicial Network entail should be improved in order to facilitate effective cooperation amongst national courts in such litigation. In both aspects of the matter, mechanisms which the European Competition Network incorporates could set models. Naturally this proposal would raise sensitive questions regarding national procedural autonomy, but one should bear in mind that harmonisation of either national substantive standards regarding the passing-on defense and indirect purchaser standing, or alternatively strong mechanisms of judicial cooperation, would prove inevitable for an effective European private enforcement regime to emerge. In the lack of both, the result will either be forum shopping and a chaos of indirect and direct purchaser damage actions before various courts, raising risks of inconsistency and multiple recoveries, as the US experience clearly illustrates, or total failure of the efforts to invigorate private enforcement in

\footnotetext{
${ }^{150}$ European Commission Notice, supra note 143, at para. 13 et seq.
} 
Europe. ${ }^{151}$ In that sense, it is surprising that the Commission's Green Paper proposes substantive policy alternatives and largely misses procedural aspects of private enforcement inextricably connected to such proposals. Under the findings of this paper this appears a strategic mistake and therefore the Commission is hereby called on to address those issues in its widely expected White Paper.

\section{Conclusions}

This paper explored the US experience regarding passing-on defense and indirect purchaser standing and the reasons behind the current initiative for a policy change in order to draw policy lessons for the Community. Such an analysis appears particularly timely considering the Commission's Green Paper which proposes alternative policy designs regarding these issues and the White Paper which is yet to come.

There are dramatic divergences between the American understanding of the goal of private enforcement and the European doctrine of direct effect. Due to such divergence, it does not seem possible to propose any transatlantic policy lessons in the substantive sense. However, the US experience appears very informative in terms of the risks raised by private enforcement in a multi-level polity in the presence of diverse standards and in the lack of effective coordination mechanisms amongst the judiciary. Analysis of the current situation in the Community regarding these matters implies that there is certain evidence to believe that the multi-level indirect and direct purchaser litigation chaos which forced a policy change in the US might also happen in the Community, as at present Community law seems to have left these matters to the national laws which foresee diverse standards. On the other hand, although procedural harmonisation measures taken by the Community already provide mechanisms for the national courts to cooperate in crossborder litigation of related matters, further development and improvement of those mechanisms are necessary in order to sustain coherence and efficiency

\footnotetext{
${ }^{151}$ In that sense it is surprising that the Commission's Green Paper confines itself to substantive policy options and does not comment on procedural aspects of the matter. Some authors had criticised the Commission for overlooking the essential procedural aspects of private enforcement long before the Green Paper was issued. See e.g. Francis G. Jacobs and Thoms Deisenhofer, "Procedural Aspects of the Effective Private Enforcement of EC Competition Rules: A Community Perspective", in European Competition Law Annual 2001: Effective Private Enforcement of EC Antitrust Law, Claus-Dieter Ehlermann, Isabela Atansiu (Eds.), 2003, Oxford-Portland Oregon, 187-252.
} 
of cross-border litigation. Such an action would probably provoke some resistance at the national level as it would raise questions of national procedural autonomy, but it should be born in mind that either substantive or procedural harmonisation would prove necessary if establishment of an effective private enforcement regime is a priority for the Community. From this perspective, it appears surprising that the Commission's Green Paper confines itself to substantive policy proposals to the large extent and misses procedural aspects of the problem. Consequently, conclusions of this Paper might also be taken as a warning to the Commission and a suggestion that those issues be addressed by the widely expected White Paper. 